\title{
Customer Satisfaction on Barista Service
}

\author{
Wim J Winowatan ${ }^{1}$, I Putu Suarta ${ }^{1}$, Murdiani Sukarana ${ }^{1}$ \\ Email: wimjohannes12@gmail.com \\ ${ }^{1}$ Food and Beverage Management, Hospitality Department, Tourism Polytechnic Makassar, \\ Indonesia
}

Received: September 25, 2021

Revised: October 17, 2021

Accepted: November 1, 2021

\begin{abstract}
This study aims to determine consumer satisfaction with barista services. The method in this study is qualitative using a descriptive approach. The method of data collection in this study was done through observation, interviews with a list of questions and documentation. The results of the study show that consumer satisfaction with barista services in general is satisfied with the barista services and coffee drinks served, but most of the guests who visit are only coffee drinkers, not coffee connoisseurs. This needs to be followed up so that consumers or guests can better understand the existence and services of Baristas, this is because consumers or guests are only coffee drinkers, not coffee connoisseurs and only choose the type of coffee provided. The existence of the Barista and the services available at the cafe only provide coffee based on the needs of consumers or guests and there is still a lack of availability of very limited and expensive equipment that must be spent for each equipment needed.
\end{abstract}

Keywords: Customer Satisfaction, Barista Service, Hotel

Introduction

Hotels and restaurants support each other's existence which is expected to provide service satisfaction to guests or tourists so that it is possible to return to visit. The progress of a hotel and restaurant business service can be determined by the two elements, namely the Accommodation Industry and the Food Service Industry (Kelliher \& Perrett, 2001). Even a hotel is said to be successful in achieving its goals if the income from the Food Service Industry is greater than that of the Accommodation Industry.

The hospitality service industry, commonly referred to as the Hospitality Industry or an industry that sells hospitality services, consists of; (1) Accommodation Industry (2) Food Service Industry. The method used by the hotel to attract guests to come and stay at the hotel time and again was to provide a lot of delicious food to the guests because at that time the restaurant in a hotel was only provided to eat guests who stay at the hotel. Guests from outside the hotel are not allowed to eat in the restaurant in the hotel. On the other hand, guests staying at a hotel may not eat at the restaurant outside the hotel. but now the restaurant in a hotel is open to anyone, whether guests staying at the hotel or those who come from outside and don't stay at the hotel. Likewise, guests staying at a hotel are free to eat anywhere; in restaurants inside the hotel, other hotel restaurants, or restaurants scattered outside the hotel building, thus the role of the restaurant becomes increasingly important and makes restaurants compete with each other to improve the quality of food and service as well as possible in the hope of getting as many guests as possible. so that sales / results and profits are as high as possible.

Service is provided as an action for the actions of a person or organization to provide satisfaction to customers or customers and also provide something beyond what the customer has expected (Sánchez-García \& Currás-Pérez, 2011). However, according to Moenir (2008)

Copyright $\odot$ 2021, Journal of Asian Multicultural Research for Social Sciences Study, Under the license CC BY-SA 4.0 
service is a series of activities that take place regularly and continuously covering all people's lives in society.

In this case it can be concluded that the service is an intangible product or intangible, therefore the service cannot be measured in the sense that it cannot be held but can only be felt by those who receive the service. The success of service quality is always associated with how much the customer expects (Expected service) to be obtained with the reality of the service he receives or feels (Perceived Service).

Satisfaction is the level of one's feelings after comparing the performance (or results) that he feels compared to his expectations (Dugguh \& Dennis, 2014). So the level of satisfaction is a function of the difference between perceived performance and expectations. Customers can experience one of three general levels of satisfaction (Jahanshahi et al., 2011). If performance is below expectations, the customer is disappointed. If the performance matches expectations, the customer is satisfied. If performance exceeds expectations, the customer is very satisfied, happy or excited

According to Kotler \& Keller in Apriyani \& Sunarti (2017), satisfaction is a person's feeling of pleasure or disappointment that arises after comparing the performance (outcome) of the product thought to the expected performance. This study aims to determine consumer satisfaction with barista services

\section{Methods}

This study uses a qualitative approach. This research is located in Pare-pare City, South Sulawesi Province by reviewing data from interviews and documentation. The techniques used in that are; document analysis, observation, and interviews as well as direct observation or observation. As the final process after the data is collected, the researcher begins to carry out data analysis. Data analysis of this research was carried out based on the steps of analysis of qualitative research data proposed by Interactive from Miles \& Hiberman, namely: (1) data collection, (2) data reduction; (3) Presenting data, and; (4) conclude data

\section{Results and Discussion}

\section{Customer Satisfaction with Barista Service}

Consumer satisfaction is the level of a person's feelings after comparing the performance (or results) he feels compared to his expectations (Angelova \& Zekiri, 2011; Rao \& Sahu, 2013). So, the level of satisfaction is a function of the difference between perceived performance and expectations. The customer or consumer can experience one of three general levels of satisfaction. If the performance is below expectations, the customer or consumer will be disappointed. However, if the performance matches expectations, then the customer or consumer will be satisfied. Satisfaction can also be assumed to be a feeling of pleasure or disappointment that arises after comparing the performance (results) of the product that is thought to the expected performance. Consumer satisfaction is a situation shown by consumers when they realize that their needs and desires are as expected and well fulfilled (Torres \& Kline, 2013). Measurement of consumer satisfaction can be done by:

\section{Complaints and Suggestion System}

Companies that provide full opportunities for customers to express opinions or complaints, are customer-oriented companies. In observations and research results revealed through interviews with consumers about coffee services by Baristas, it can be concluded that, complaints and suggestions are not found because consumers are only coffee drinkers, not coffee connoisseurs, in general consumers only take advantage of the facilities provided by cafes or coffee shops. 
Customer Satisfaction Survey The company conducts a customer satisfaction survey on the quality of services or products. The survey was conducted by distributing questionnaires by company employees to customers. Through surveys, companies can find out the advantages and disadvantages of these products or services, so they can make improvements to things that are considered lacking by customers. Measurement of customer satisfaction with the survey method can be done in a number of ways, including: Directly Reparted Satisfaction An expression that is conveyed directly about his satisfaction with the services he receives. Derived Dissatisfaction Respondents were asked how much they expected a certain attribute and how much they felt. Problem Analysis Respondents were asked to write down the problems they faced related to the company's offer. In addition, respondents were also asked to write down the improvements they suggested. Importance / Performance Ratings Respondents can be asked to rank the various elements (attributes) of the offering based on the degree of questioning of each element and how well the company performs in each element. From observations and research on consumers about coffee services by Barista, it can be concluded that both the manager and the Barista are less than optimal in conducting a Satisfaction Survey to consumers. The results of interviews, in general, consumers only as drinkers not as coffee connoisseurs.

Ghost Shopping This method is carried out by employing several companies (ghost shoppers) to act as buyers at competing companies, with the aim that these ghost shoppers can find out the quality of service, product quality of competing companies so that they can be used as corrections to the quality of service and company products. Ghost Shopping This method is carried out by the Barista business manager to determine the existing competitiveness. So that they can carry out strategies to meet the needs and desires of consumers as coffee drinkers.

Lost Customer Analysis This method is carried out by the company by contacting customers who have not visited for a long time or make purchases at the company because they have moved to competing companies. In addition, the company can ask the reasons for switching customers to competing companies.

Based on the results of the interview, the Lost Customer Analysis was not carried out by the manager or the barista. Only expect guests or consumers who come and do not collect data about any customers who have come and do not come back. The guest name data collection system is not managed properly.

If you understand about consumer satisfaction, it can be interpreted as an effort to fulfill the needs and desires of guests. Therefore, to meet the needs and desires of guests so that consumers feel satisfied, it is necessary to have a strategy that must be carried out as described.

Based on the description that has been described about customer satisfaction, it can be concluded that customer satisfaction with barista services is generally satisfied with service. However, in terms of meeting the needs of coffee drinks in general, only as a coffee drinker, not as a coffee connoisseur.

Consumer Satisfaction, Satisfaction is the level of a person's feelings after comparing the performance (or results) he feels compared to his expectations. So the level of satisfaction is a function of the difference between perceived performance and expectations. Customers can experience one of three general levels of satisfaction. If performance is below expectations, the customer is disappointed. If the performance matches expectations, the customer is satisfied. If performance exceeds expectations, the customer is very satisfied, happy or excited

Satisfaction is a person's feeling of pleasure or disappointment that arises after comparing the performance (results) of the product thought to the expected performance, consumer satisfaction is a situation shown by consumers when they realize that their needs and desires 
are as expected and well fulfilled. Meanwhile, according to consumer satisfaction is a positive feeling of consumers related to the product / service during use or after using the service or product.

Satisfaction is when consumers compare their performance expectations with (actual product performance) namely the perception of product quality (Winowatan et al., 2020). If the quality is far below expectations, they will experience emotional dissatisfaction. If performance exceeds expectations, they will feel emotional satisfaction. If performance is considered equal to expectations, consumers experience expectancy confirmation. The key to retaining customers is customer satisfaction. Satisfied customers will make repeat purchases, say good things about the company to others (recommendations), pay less attention to competing brands and product advertisements, and buy other products from the same company.

Measurement of consumer satisfaction according to, can be done by:

\section{Evaluation and Suggestion System}

Companies that provide a sheet in the form of what is usually called a guest comment where guests can submit complaints, input, suggestions and evaluations to the company. This is to make improvements if there is a shortage in the services provided by the company.

\section{Guest satisfaction assessment}

The company conducts an assessment of customer guest satisfaction on the quality of service or product. The survey was conducted by approaching consumers by telephone, visiting directly, or asking questions regarding the quality of services or products provided by the company, distributing questionnaires by company employees to customers.

\section{Ghost Shopping}

This method is implemented by employing several companies (ghost shoppers) to act as buyers at competing companies, with the aim that these ghost shoppers can find out the quality of service and product quality of competing companies so that they can be used as corrections to the quality of service and company products.

\section{Lost Customer Analysis}

This method is carried out by the company by contacting customers who have not visited for a long time or making purchases at the company because they have moved to a competing company. In addition, the company can ask the reasons for switching customers to competing companies.

Consumer satisfaction is a person's feelings of pleasure or disappointment that arise after comparing the expected product performance (results) to the expected performance or results. If performance is below expectations, consumers are dissatisfied. If performance meets expectations, consumers are satisfied. If performance exceeds expectations, consumers are very satisfied / happy.

Based on the description above regarding consumer satisfaction, it can be concluded that customer satisfaction with barista services is generally satisfied in service, but in terms of meeting the needs of coffee drinks, in general, only as coffee drinkers, not as coffee connoisseurs.

Based on the presentation of the data that has been described, it can be concluded that basically consumers do not have a perception or do not understand about the existence of baristas and coffee services but expect the development of the Cafee \& Resto informal restaurant business so that local revenue can increase. So that the role of the barista is needed to be developed as

Copyright (C 2021, Journal of Asian Multicultural Research for Economy and Management Study, Under the license CC BY-SA 4.0 
well. This is to meet the needs and desires of guests in serving coffee drinks and it is expected that consumers or guests feel fulfilled their needs and desires so that consumers feel satisfied.

Likewise, guest satisfaction with the barista service is basically satisfied, it's just that most guests are just drinkers, not coffee drinkers. This is based on the results of the researcher's interview with guests Samuel and Anton at the Bukit Amais Cafe, explaining that:

Our existence at this cafe is only as coffee drinkers, not as coffee connoisseurs, we only order coffee drinks because we are drinkers, not connoisseurs. The atmosphere we enjoy and we are satisfied with the service and including the atmosphere (interviewed on 11 July and 25 July 2021)

Similarly, the results of our interview with the waiter Ade at the Bukit Amais Cafe about the guest's response to the waiter service, explained that:

There are only a few guests who come to the cafe as coffee connoisseurs, while there are very many as drinkers. And we have conducted a survey to guests about service and coffee drinks in general, guests are satisfied with the service.

We also conducted interviews with D'Carlos guests with the priest, explaining that:

Basically I only came to this cafe just to drink coffee and I was satisfied with the service and the coffee served (interview on July 25, 2021)

Based on the results of interviews, it can be concluded that consumers are basically satisfied with the service and coffee drinks provided at cafes in the city of Pare-Pare, but most consumers are only coffee drinkers, not coffee drinkers.

The results of each of the statements that have been described are reviewed by the researcher, especially the comments submitted by the informants. Broadly speaking, the data from the interviews were sourced from informants who were considered quite professional in providing answers to any questions concerning the formulation of the problem as formulated by the researcher. The data from the interviews were processed after the results of the interviews were obtained from the informants who had been set. Therefore, baristas are very much needed in their development as well as in the development of informal restaurant businesses in the city of Pare-Pare, based on this, the fulfillment of the needs and desires of guests, especially in Barista services and coffee drinks can be fulfilled because in general the results of interviews with guests stated that they were satisfied with the service. Barista services and coffee drinks, although in general they are still categorized as coffee drinkers, not coffee connoisseurs.

The interview data illustrates that in general, both as guests and baristas, informal restaurant entrepreneurs, in this case coffee shops or cafes, have different perceptions about the existence of baristas and their services, whose existence is very necessary.

Service Quality basically refers to meeting the needs and desires of guests. Service delivery is absolute to measure a success. And in terms of the best or excellent service, it will appear if the elements of meeting the needs and expectations of guests can be met. This is aligned with existing concepts, namely, attitude, attention, action, ability, appearance, and accountability.

\section{Conclusion}

Consumer satisfaction with the barista service in general, consumers are satisfied with the barista service and coffee drinks served, but most of the guests who visit are only coffee drinkers, not coffee connoisseurs. 


\section{References}

Angelova, B., \& Zekiri, J. (2011). Measuring customer satisfaction with service quality using American Customer Satisfaction Model (ACSI Model). International journal of academic research in business and social sciences, 1(3), 232.

Apriyani, D. A., \& Sunarti, S. (2017). Pengaruh Kualitas Pelayanan Terhadap Kepuasan Konsumen (Survei Pada Konsumen the Little a Coffee Shop Sidoarjo). Jurnal Administrasi Bisnis, 51(2), 1-7.

Dugguh, S. I., \& Dennis, A. (2014). Job satisfaction theories: Traceability to employee performance in organizations. IOSR journal of business and management, 16(5), 1118.

Jahanshahi, A. A., Gashti, M. A. H., Mirdamadi, S. A., Nawaser, K., \& Khaksar, S. M. S. (2011). Study the effects of customer service and product quality on customer satisfaction and loyalty. International Journal of Humanities and Social Science, 1(7), 253-260.

Kelliher, C., \& Perrett, G. (2001). Business strategy and approaches to HRM-A case study of new developments in the United Kingdom restaurant industry. Personnel Review.

Miles, M. B \& Michael H. (2007). Analisis Data Kualitatif. Jakarta. Universitas Indonesia Press

Moenir, H. A. S, (2008) Manajemen Pelayanan Umum Di Indonesia, Bumi Aksara. Jakarta

Rao, P. S., \& Sahu, P. C. (2013). Impact of service quality on customer satisfaction in hotel industry. IOSR Journal of Humanities and Social Science, 18(5), 39-44.

Sánchez-García, I., \& Currás-Pérez, R. (2011). Effects of dissatisfaction in tourist services: The role of anger and regret. Tourism Management, 32(6), 1397-1406.

Torres, E. N., \& Kline, S. (2013). From customer satisfaction to customer delight: Creating a new standard of service for the hotel industry. International Journal of Contemporary Hospitality Management.

Winowatan, W., Suarta, I. P., \& Sukaran, M. (2020). Analisis Kompetensi Dalam Memaksimalkan Pelayanan Prima Pada Usaha Restoran Di Kabupaten Polewali Mandar Sulawesi Barat. Jurnal Ilmiah Manajemen Emor (Ekonomi Manajemen Orientasi Riset), 3(2), 119-135 